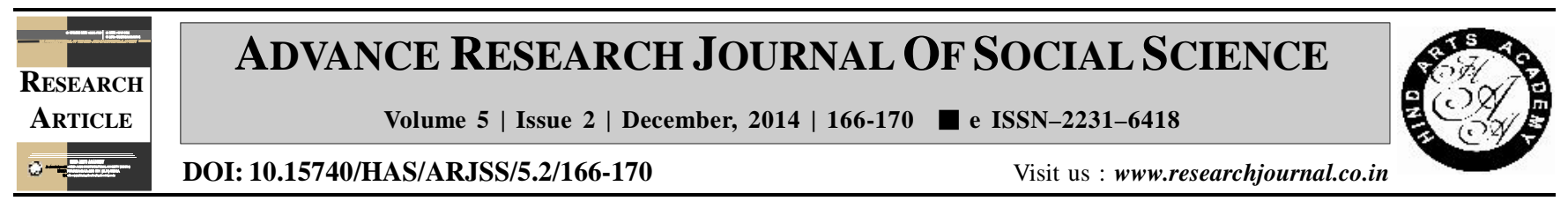

\title{
Socio-economic status of emu farmer in Marathwada region of Maharashtra state
}

V.G. Landge*, D.N. Hedgire, R.A. Kolambkar and P.R. Mule ${ }^{1}$

Department of Agricultural Economics, College of Agriculture, Vasantrao Naik Marathwada Krishi Vidyapeeth, PARBHANI (M.S.) INDIA

${ }^{1}$ Department of Animal Husbandry and Dairy Science, College of Agriculture, Vasantrao Naik Marathwada Krishi Vidyapeeth, PARBHANI (M.S.) INDIA

(Email: varshalandge002@gmail.com)

\section{ARTICLE INFO :}

$\begin{array}{lll}\text { Received } & : & 13.08 .2014 \\ \text { Revised } & : & 03.11 .2014 \\ \text { Accepted } & : & 16.11 .2014\end{array}$

KEY WORDS :

Socio- economic status, Emu farmer

HOW TO CITE THIS ARTICLE :

Landge, V.G., Hedgire, D.N., Kolambkar, R.A. and Mule, P. R. (2014). Socio-economic status of emu farmer in Marathwada region of Maharashtra state, Adv. Res. J. Soc. Sci., 5 (2) : 166-170.

*Author for correspondence

\begin{abstract}
The data on selected socio-economic aspects were collected by interviewing the respondent farmers in the Marathwada region of Maharashtra state. The overall total land holding of sampled emu farmer was 5 hectares with 14.14 emu birds. The average size of family was 6.13 . Average irrigated area was 3.92 ha and rainfed area was 1.06 ha. The study revealed that crop like cotton, soybean, groundnut, wheat, Rabi jowar were mostly grown in the study area. In selected area, one emu farmer's (a case study) total land holding was 9 hectares with 50 pair of emu birds. The average size of family member was 5. Irrigated and rainfed area were 4.00, 4.80 ha, respectively. Average total live stock held by sample farmer was 2.12 and in case of one farmer total live stock number was 3 .
\end{abstract}

